\title{
Knowledge and Use of Wild Edible Plants in the Hula District of the Sidama Zone
}

\author{
Benta Sina ${ }^{1}$ and Hewan Demissie Degu ${ }^{2 *}$ \\ ${ }^{1}$ Dept. of Biology, Hawassa College of Teacher Education, Hawassa, SNNPR, Ethiopia \\ ${ }^{2}$ School of Plant Science and Horticulture, College of Agriculture, Hawassa University, Hawassa, SNNPR (14 17), Ethiopia
}

Article History

Manuscript No. AR1384b

Received in $13^{\text {th }}$ May, 2015

Received in revised form $3^{\text {rd }}$ June, 2015

Accepted in final form $7^{\text {th }}$ June, 2015

\section{Correspondence to}

*E-mail: hewan.dd@gmail.com

\section{Keywords}

Wild, edible, sidama, food security, ethno-botany

\begin{abstract}
Sidama Zone is found in the Southern Nation Nationalities and People Regional State of Ethiopia. The zone has thirty-three districts. Wild edible plants are means of survival during war, political unrest, and food insecurity in this Zone. The objective of this research is to describe indigenous knowledge about wild edible plants based age, gender and education level in Hula district. Data on the use of wild edible plant were collected through semi structured interviews with key informants. The textual data were coded, quantified and analyzed with R software. A total of 50 wild edible plants belonging to 46 genera and 31 botanical families were reported in Hula district. Families Moraceae (12.5\%), Rosaceae (12.5\%), Rubiaceae (9.5\%), Fabaceae $(9.5 \%)$ and Solanaceae $(9.5 \%)$ were found in the area. About $68 \%$ of the wild edible plants were trees. These wild edible plants were marketable. Further more some of the wild edible plants have medicinal values for human and livestock diseases. The popular food-category of wild edible plants is fruit eaten raw, and herbs eaten cooked as vegetables. There is significant difference $(p<0.05)$ on the knowledge of wild edible plants between different sex and age groups. Social, economic and cultural factors contributed for consumption and avoidance of some edible wild plants. The poor communication system, on the other hand, has hindered the knowledge transfer from elders to youngsters and among different genders. The demand is growing for most of the wild plants regarded as local specialties, and reflect regional and cultural identity.
\end{abstract}

\section{Introduction}

The security of adequate human nutrition is a challenge for local, regional and global governments (Grafton et al., 2015). Many government and non-government organizations are working to tackle food security for each and every corner of the ever expanding world in terms of population (Friel and Ford, 2015; Qi et al., 2015; Rivers et al., 2015). However many of the institutions overlooked answering the important question of food availability, accessibility, palatability and preference of different societies. These questions could be influenced more by the difference in geography, demography, socioeconomic status, ethnicity, culture and religion of the society.

In the past, human beings intensified agriculture by clearing forests to grow more food for the growing population. However, this practice has its own disadvantage as witnessed by increased level of environment degradation and soil erosion (Demessie et al., 2015; Joshi et al., 2015). This accelerated clearing of forest resources contributed for the emission of greenhouse gases which contributed for increasing the global temperature (Ojelel and Kakudidi, 2015; Bahru, As faw and Demissew, 2014). The increased global temperature has drastic effect for sustainable growth and management of the ecosystem.

All these problems urge researchers, policy makers and educators to devise resilient food production system that can address the issue of appropriate science and technology for sustainable development. To this effect, ethnic, cultural, gender and socio economic level of farmers should be considered at the grass root level. One method to address the issue of sustainable development is by understanding the cultural and indigenous knowledge of people on plants in particular regions and ethnic groups. Among the plants which can bring sustainable development by keeping the ecosystem diversity are wild edible plants. Such plants are gathered frequently by different age and gender group of society in particular geographical environment. Collection of wild edible plants is 
low in volume since they are often collected only for household consumption.

Wild edible plants play important role in food security in subSaharan Africa (Salih and Ali, 2014). They are diverse, provide micronutrient, vitamins and diverse taste to the households (Afolayan and Jimoh, 2009; Basu et al., 2014; Ju et al., 2013; Kidane et al., 2014a; Onyekwelu et al., 2015; Sneyd, 2015). Many wild edible plants are gathered by poor people from different geographic, cultural and ethnic groups (Fentahun and Hager, 2009). And most of the time wild edible plants are gathered without incurring cost. This indicate they can be used to generate income to the poor people. In addition, they can be source of food during time of emergency, political unrest, climate change and food insecurity (Addis et al., 2005).

Since they adapted to a particular environment, they can be tolerant to environmental stress. However, the advantage of these wild edible plants can be hampered by poor policy design and lack of information by the community members. Although wild edible plants are important dietary source for rural communities, their contribution to food security is underestimated by educators, scientist, researchers and policy makers.

Ethiopia is a country which is hosting more than 80 ethnic and about 78 language groups (Salawu and Aseres, 2015). One of regional states with diverse ethno-linguistic in Ethiopia is the Southern Nation and Nationalities and People Regional State (SNNPR). The region hosts more than 50 language and Ethnic groups. The presence of diverse language is evidence for the presence of diverse cultural knowledge about wild edible plants.

One of the major ethnic group who live in SNNPR are Sidama people (Danver, 2015). The Sidama people used to rear animals, and had been nomadic with live-style of hunting animals-and gathering plants (Danver, 2015). Ethnographic and folkloric studies draw attention to the historical view of food and nutrition among the Sidama people (Bizuayehu, 2008). Furthermore, the relationship of gender, education level in preparing and gathering of plants mark the difference in the dietary characteristics among the people in the ethnic group (Addis et al., 2005).

Settlement in and near villages of Gedio, Oromo and Wolaita ethnic groups in recent decades have led to a shift in traditions, and practice of difference food sources. Furthermore, because of the religion (Christianity and Islam), the communities began practicing fasting in fasting days and seasons. This led the people to be vegetarian during fasting. In the ancient times the food of Sidama people was more dominated by Enset based diet which was eaten with beef, goat or sheep meat and milk. However, after the expansion of the Imperial system, the community starts adapting to new food styles which are mainly the practice of the central regional state of Ethiopia. Of the introduced foods are teff, potato, tomato and corn. Currently, two types of food culture, urban and rural, are observed. This further brought difference in the way the food is prepared and purchased. This practice has changed the meaning and place of wild edible plants in the current society.

In SNNPR government of Ethiopia, research on wild edible plants has received significant attention in various researchers. FAO stressed the conservation, promotion and sustainable utilization of neglected food plants requires various actions including inventorying, in situ conservation of wild relatives and commercialization (Duncan, 2015).

Much values from wild edible plants remain undocumented because their products are used locally without being reflected in national or international markets. Therefore, systematic documentation of indigenous knowledge regarding the identity and use of wild foods by rural communities is crucial. Both biological resources and indigenous knowledge are diminishing with habitat destruction and a growing disinterest among the younger generation. The data presented in this study focuses specifically on the wild edible plants used in Hula district of Sidama Zone in the SNNPR of Ethiopia. The main research questions posed are 1) what are the wild edible plants known in the selected districts? And 2) is there difference in the knowledge of wild edible plants among the member of the community? Following research questions 1 and 2, we tested the hypothesis that cultural consensus based on knowledge of wild edible food plants is affected by underlying variation in gender and age group of the community. The study provides a detailed overview of wild edible plants as means of food security; and describes the unique cultural traditions surrounding level of knowledge and practice of wild edible plants observed by this group of people. The data will aid in enhancing the value of such locally produced food sources.

\section{Materials and Methods}

The research was conducted Sidama Zone of the SNNPRS in eight rural sub districts of Hula district from the November 2012 to June 2013. The district is located at the coordinates ${ }^{\circ} 25^{\prime} 30^{\prime \prime}$ to $6^{\circ} 36^{\prime} \mathrm{N}$ and $38^{\circ} 27^{\prime} 08^{\prime \prime}$ to $38^{\circ} 41^{\prime} 06^{\prime \prime} \mathrm{E}$ and altitude of 1601 to $2850 \mathrm{~m}$. The Population of the district is 146,243 (women=73145, men=73098). The eight sub-districts were selected based on climate condition, the plant population and diversity of plant species. Chelbessa, Honkomolicha, Luda and Bentiwata were from Dega climatic condition while 
Haleka, Worare, Getama and Faficho Fuko were from Woina Dega. Majority of the population, $72.5 \%$, reside in rural areas. The livelihood of the people is based on agriculture, cattle rearing and other activities. Wild edible plants supplement the economy largely for sales.

Data were collected using interview guide. After introducing the research team and research objectives to the head of the village, an open-ended interview was conducted to collect demographic and social data about the village. A brain storming focus group interview was also made with a mixed gender group by the first author. The next day, two group interviews were conducted with people who are said to be knowledgeable on wild edible plants, and were selected by the head of the village. The key informants included different gender and age groups. Questionnaire was used to collect information on nomenclature, use, and preparation of wild edible plants. The questionnaire was administered to 120 participants ( 32 females and 88 males) who were older than 25 years, and lived in the villages for long.

Plant names mentioned by participants during the interviews were recorded in Sidama language, their native tongue, and transliterated into scientific names. Plant material was collected, pressed and drenched into alcohol for herbarium vouchers and subsequent identification. The identification of the wild edible plants was made based on the Flora of Ethiopia and Eritrea through comparison with authentic specimens, illustrations and with the assistance of experts at National Herbarium of Addis Ababa University.

Percentage, and bar charts were used to summarize the data. Analysis of variance $(\alpha=0.05)$ was used to determine the significance effect of gender, education level and age group of the informants on their knowledge of wild edible plants.

\section{Results and Discussion}

\subsection{Diversity of Wild edible plants}

The study identified and documented 50 wild edible plant species classified into 46 genera and 31 families. List of all the recorded wild edible plants species with their families, local name, habit and plant part used, were presented (Table 1). From these plant groups, the most prevalent ones are Moraceae (12.5\%), Rosaceae (12.5\%), Rubiaceae (9.5\%), Fabaceae $(9.5 \%)$ and Solanaceae $(9.5 \%)$. They had the highest proportion of edibles families with more than 3 species (Figure 1). This result showed that Hula district is rich in wild edible plants as shown by the presence of 50 species exhibiting wide taxonomic diversity. The diversity has also been made obvious in the elaborate system of traditional naming of plants (based on morphology of a plant part or its medical uses), the indigenous knowledge engraved in each wild edible plant species name, and knowledge about the edible part, and habits (Figure 2). This number of diverse taxonomic groups of wild edible plants have been observed in different regional state of Ethiopia (Addis et al., 2005; Kidane et al., 2014b; Molla et al., 2011), other African countries (Afolayan and Jimoh, 2009; Lamien-Meda et al., 2008), Asia (Bhattarai et al., 2009; Kang et al., 2014; Kayang, 2007), Europe (Jman Redzic, 2006; Nedelcheva, 2013; Nedelcheva and Dogan, 2011; Pardo-deSantayana et al., 2007) and Latin America (Campos et al., 2015). In reference of Ethiopia, many researchers reported the wide diversity of wild edible plants. For example, 38 wild edible plants species were reported in Debub Omo Zone in Kara and Kwegu (Teklehaymanot and Giday, 2010). About 58 species were found in Chelia district (Tebkew et al., 2014). Of all the areas in Ethiopia, the highest number of wild edible plants, 137 species, were identified in Konso region (Addis et al., 2013a). The study shows that the cultural amalgamation and closeness of the study area to the city or not, whether the people are pastoralists or mixed farmers seems to have affected about the number of preserved wild edible plant species.

\subsection{Growth habit of the wild edible plants}

The growth forms of the species include trees $(36 \%)$, herbs (32\%), shrubs (24\%) and climbers $(8 \%)$. Trees and herbs make up the highest proportion $(68 \%)$ of the wild edible species (Figure 3). This could be related to the fact that they are often harvested from patches of forests distantly located from resident areas. The finding agrees with the general pattern of dominance of tree species seen in most edible wild plant inventories in Ethiopia and other countries (Addis et al., 2005; Assefa and Abebe, 2014; Tebkew et al., 2014). This also indicated the use of these plants during the time of emergency and food scarcity. This fact has been documented by different authors that people tend to use wild edible plants during time of war, hunger and food scarcity (Addis et al., 2005; Assefa and Abebe, 2014; Tebkew et al., 2014). This could explain the situation in Hula district since the region undergone extreme bad weather condition (drought) and city expansion by clearing forest cover. With the current effect of climate change, herbal and tree species of wild edible plants could play a significant role among small holder farmers to alleviate the problem of hunger, food shortage and malnutrition. Since the wild edible plants have adapted to the area, they have greater ability to cope with the extreme climate change and adverse effects compared to conventional crops.

\subsection{Consumed plant parts}

From the part of the wild edible plants, about $62 \%$ of fruits, 
$18 \%$ of shoot, another $18 \%$ of flower/nectar and $12 \%$ tubers roots and barks are edible (Figure 4). The increased use of wild fruits compared to other part of the plant indicates that the plants are used more during season of food shortage since eating fruit do not take much time to prepare. Those who feel hungry harvest from the natural growing environment and eat without waiting for cooking or preparation. This further explains why the communities have much knowledge about the increased number of wild fruit plants. Similar trend has been reported in Konso, Chilga (Tebkew et al., 2014), Chelia district of Ethiopia (Regassa et al., 2015a), and Oblanga sub-County of Uganda (Ojelel and Kakudidi, 2015). The explanation behind trees dominating the edible part of wild edible plants is their importance during time of emergency.

\subsection{Mode of consumption}

The mode of consumption of wild edible plants were raw $(68 \%)$, flowers $(6 \%)$, herbal tea $(4 \%)$, liqueurs $(6 \%)$ and cooked vegetables (14\%) (Figure 5). The highest number of raw mode of consumption can be explained by the fact that wild fruits are more favored by children. For example, the fruits of Monardica foetida is used by children to suck the pulpy covering of the seeds. The barks of both Apodytes dimidiate and Canthium oligocarpum sub sp. oligocarpum were used as fresh juice. Other uses of the wild edible plant include extraction of oil from the seed and tuber. Most of the identified wild edible plants also have wide usage in the other part of Ethiopia (Lulekal et al., 2013; Molla et al., 2011; Regassa et al., 2015b; Tebkew et al., 2014). Many wild edible species (Arisaema flavum (Forssk.) Schott Morus alba L.,
Rubus volkensii Engl., Sauromatum venosum (Ait.), Kunth and Solanum nigrum L.) were found only in Hulla ethnographical area. Most of these plants are currently rarely used, but more or less used as a substitute as medicine for infertility, and as a food during famine. Discussion with the community revealed that gathered fruits and vegetables were used as basic food components in the past (Table 2). These wild edible plants are currently replaced by cabbage and kale. Still many poor families rely on the wild vegetables mixed with corn or Ensete extracts. The high consumption of wild edible plants in the form of fruit and vegetable might be explained by their nutritional value and their desirable taste (Addis et al., 2013b; 2014b; Boedecker et al., 2014; Getachew et al., 2013).

\subsection{Marketability}

In addition to food value, the identified species were marketable and provide the opportunity to supplement household income. For example, many of the wild edible plants play a significant source of income by selling them for medicines, timbers, furniture, dyes, shelter, fibers and religious and cultural ceremonies. This practice was actually observed by the researchers in the study areas where some of the wild edible plants were sold at local market. For example, Yushania alpina (Leemmicho) is sold for lucrative purpose. Market surveys results showed that the current prices of highland bamboo, Rhamnus prinoides range from 5-50 Ethiopian Birr. Of the recorded species, 15 species $(30 \%)$ were marketed as edible vegetables, at local markets as in Dela (Getamakebele market), Cirone market, Qawado (Bentiwatakebele market) and Hagere selam, administrative city of Hula district (Table

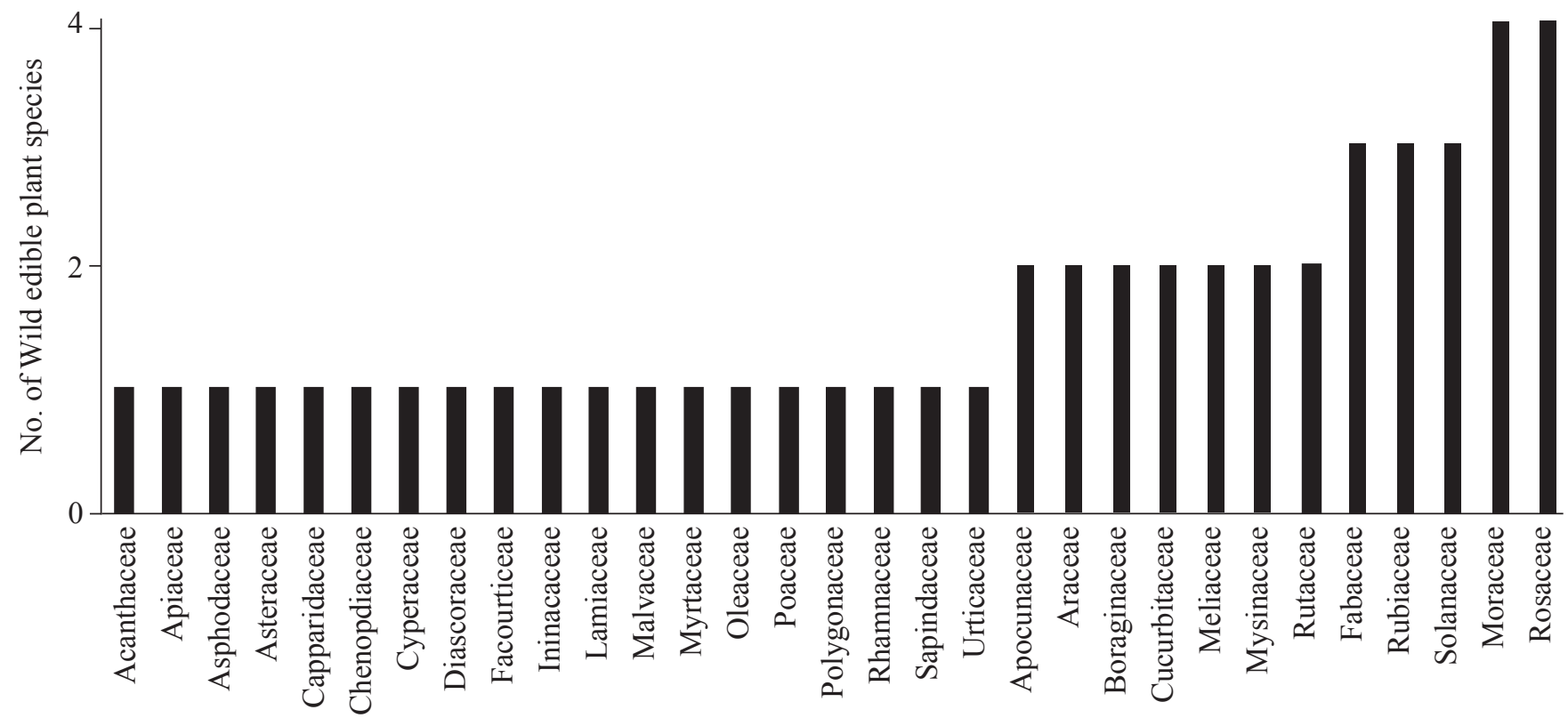

Figure 1: Species frequency of among each Family

Family Name 

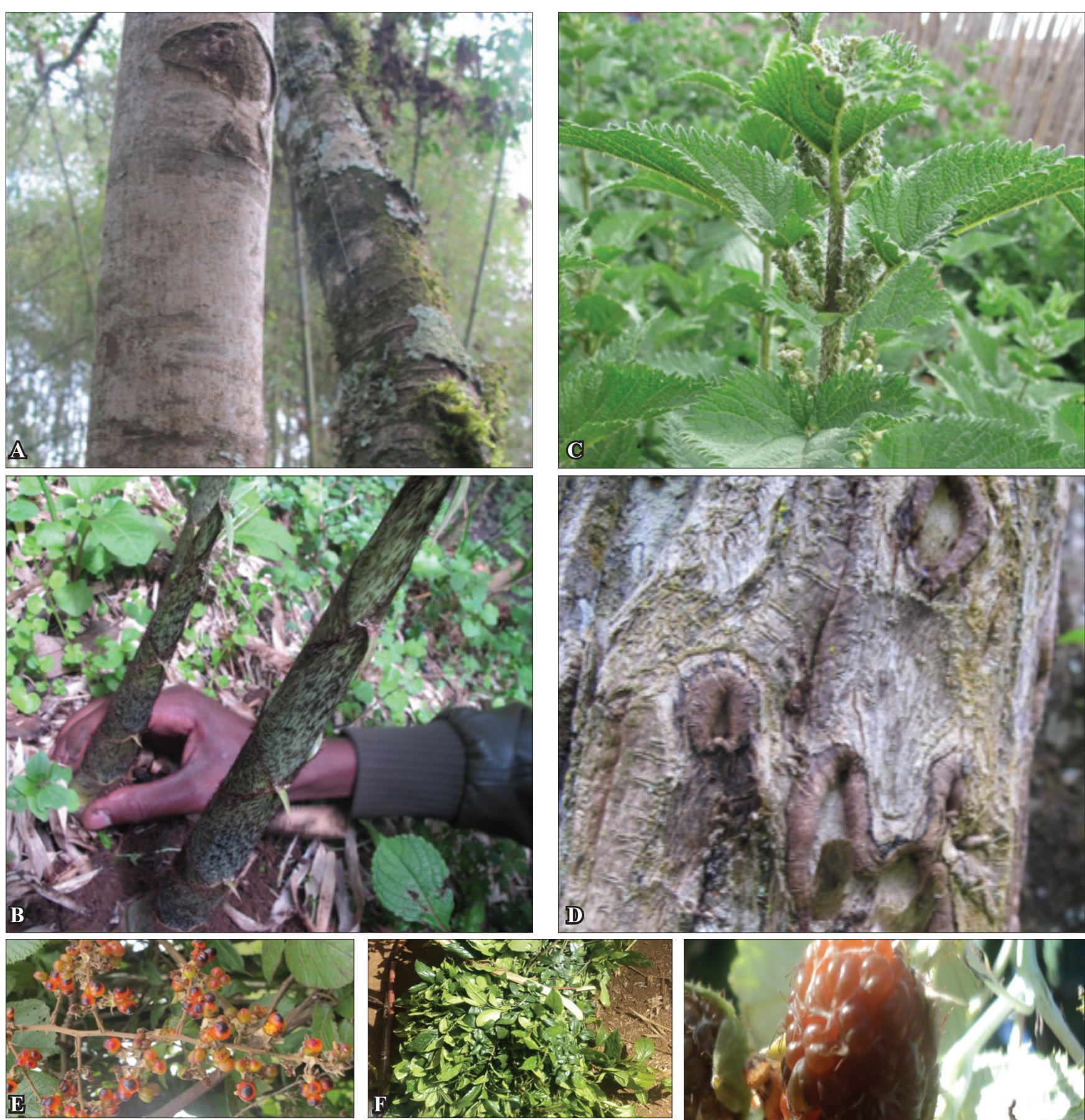

Figure 2: Representative photographs of wild edible plant from the Hula subdistric. A: Allophyllus abyssinicus, Local name: Xonxoloma; B: Yushania alpina,

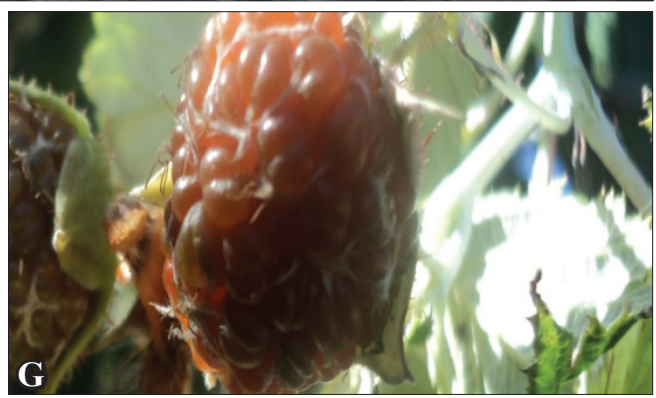

Local name: Leemmicho; C: Urtica simensis Steudul, (Loacl name: Laleessa); D: Canthium oligocarpum, Loacl name: Kincho; E: Rubus volkensii Engl., Loacl name: Allichchu Go'ra; F: Rhamnus prinoides, (Loacl name: Xaddo); G: Morus alba L. Loacl name: Boowili Go'ra

2). The findings also showed that Solanum nigrum, Urtica simensis, Yushania alpina, Olea europaea sub sp. cuspidata and Rhamnus prinoides were highly acknowledged wild edible plants for their socio-economic significances, and are marketed by all age groups. On the other hands, Morus alba,
Vepris dainelli, Rubus volkensii and Syzygium guineense were marketable wild edible plants by children. This confirms that some wild edible plants contribute for the income generating mechanism of the small holder farmer in the study area. Furthermore, the ability of the children to generate income 


\begin{tabular}{|c|c|c|c|c|}
\hline Botanical name & Family & Vernacular name & Habit & Parts used \\
\hline Acokanthera schimperi (A.D Schweinf. & Apocynaceae & Qaraaro & Shrub & Fruit \\
\hline Allophyllus abyssinicus (Hochst) Rodalkofer & Sapindaceaea & xonxolooma & Tree & Fruit \\
\hline Apodytes dimidiata E.Mey ex. Am. & Icinacaceae & Doongiicho & Tree & Bark \\
\hline Arisaema flavum (Forssk.) Schott. & Araceae & Qolcooma & Herb & Tuber. \\
\hline Cajanus cajan (L.) Mill sp. & Fabaceae & Ceate/yemakkuatara & Herb & Shoot \\
\hline Canthium oligocarpum sub sp. oligocarpum Hiern. & Rubiaceae & Kincho & Shrub & Bark \\
\hline Carrisa spinarum $\mathrm{L}$. & Apocynaceae & Hagalcho & Shrub & Fruit \\
\hline Chenopodium album $\mathrm{L}$. & Chenopodiaceae & Raafo & Herb & Young leaf \& stem \\
\hline Cordia africana Lam. & Boraginaceae & Waaddiicho & Tree & Fruit \\
\hline Cyperus usitatus Burch. & Cyperaceae & Allaado & Herb & Bulb \\
\hline Datura stramonium L. & Solanaceae & Baanje & Herb & Flower/nectar \\
\hline Diascorea abyssinica Hochst.ex Kunth. & Dioscoreaceae & Bohe & Climber & Tuber \\
\hline Dovyalis abyssinica (A.Rich) Warb. & Flacourtiaceae & Korqiicho & Shrub & Fruit \\
\hline Ehretia cymosa Thonn. & Boraginaceae & Gidiincho & Tree & Fruit \\
\hline Ekebergia capensis Sparrm. & Meliaceae & Olooncho & Tree & Fruit \\
\hline Embelia schimperi Vatke. & Myrsinaceae & Qaanqo & Climber & Fruit \\
\hline Eriose macordifolium Hochst. ex A.Rich & Fabaceae & Shilingo/silinga & Herb & Root \\
\hline Eriose maverdickii Dewild. & Fabaceae & Qociqoo'male & Herb & Root \\
\hline Ferula communis L. & Apiaceae & Nugusa & Herb & Young shoot \\
\hline Ficus palmata Forssk. & Moraceae & Belese & Tree & Fruit \\
\hline Ficus sur Forssk. & Moraceae & Odakko & Tree & Fruit \\
\hline Ficus vasta Forssk. & Moraceae & Qilxo & Tree & Fruit \\
\hline Galiniera saxifraga (Hochst.) Bridson & Rubiaceae & Daanshiicho & Tree & Fruit \\
\hline Lagenaria siceraria (Molina) Standl. & Cucurbitaceae & Surupha & Climber & Fruit \\
\hline Lepidotrichillia volkensii (Gurke) Leroy & Meliaceae & Xabbicho & Tree & Fruit \\
\hline Justicia schimperiana (Hochst.ex A.Nees) T. Anders & Acanthaceae & Ciikkicho & Shrub & Flower/ nectar \\
\hline Kniphofia isoetifolia Steud.ex Hochst & Asphodeceae & Galade & Herb & Flower/ nectar \\
\hline Maesa lanceolata Forssk. & Myrsinaceae & Gowacho & Tree & Fruit \\
\hline Monardica foetida Schumach. & Cucurbitaceae & Ki’re & Climber & Fruit \\
\hline Morus alba L. & Moraceae & Boowili go'ra & Shrub & Fruit \\
\hline Oleaeuropaea sub sp. cuspidata (Wall. ex G. Don) Cif. & Oleaceae & Ejersa & Tree & Leaf \\
\hline Pavetta abyssinica Fresen. & Rubiaceae & Shamelcho & Shrub & Fruit \\
\hline Physalis peruviana L. & Solanaceae & Maree'ra & Herb & Fruit \\
\hline Prunus africana (Hook.f.) Kalklm & Rosaceae & Garbicho & Tree & Fruit \\
\hline Rhamnus prinoides L'Herit. R. Staddo.A.Rich. & Rhamnaceae & Xaddo & Tree & Leaf and stem \\
\hline Ritchiea albersii Gilg & Capparidaceae & Baxaraqicho & Shrub & Fruit \\
\hline Rosa abyssinica Lindley. & Rosaceae & Otila & Shrub & Fruit \\
\hline Rubus apetalus Poir. & Rosaceae & Worichu Go'ra & Shrub & Fruit \\
\hline Rubus volkensii Engl. & Rosaceae & Allichchu Go’ra & Shrub & Fruit \\
\hline Rumex abyssinicus Jaccq. & Polygonaceae & Shishoone & Herb & Stem \\
\hline Sauromatum venosum (Ait.) Kunth & Araceae & Bukki-bu're & Herb & Tuber \\
\hline Sida ovata Forssk. & Malvaceae & Qirqixxe & Herb & Leaf \\
\hline Solanum nigrum L. & Solanaceae & Xu'naayye & Herb & Leaf and stem \\
\hline Syzygium guineense (Willd.) Dc. & Myrtaceae & Duuwancho & Tree & Fruit \\
\hline Teclia nobilis Del. & Rutaceae & Hadheessa & Tree & Fruit \\
\hline
\end{tabular}




\begin{tabular}{lcccc}
\hline Thymus serrulatus Hochst. & Lamiaceae & Xooshine & Herb & Whole part \\
Urtica simensis Steudul. & Urticaceae & Laaleessa & Herb & Leaf and stem \\
Vepris dainelli (Pichi-Sperm) Kokwaro & Rutaceae & Lelcho & Tree & Fruit \\
Vernonia amygdalina Del. & Asteraceae & Hechcho & Shrub & Leaf \\
Yushania alpina K. Schum & Poaceae & Leemmicho & Tree & Young shoot \\
\hline
\end{tabular}

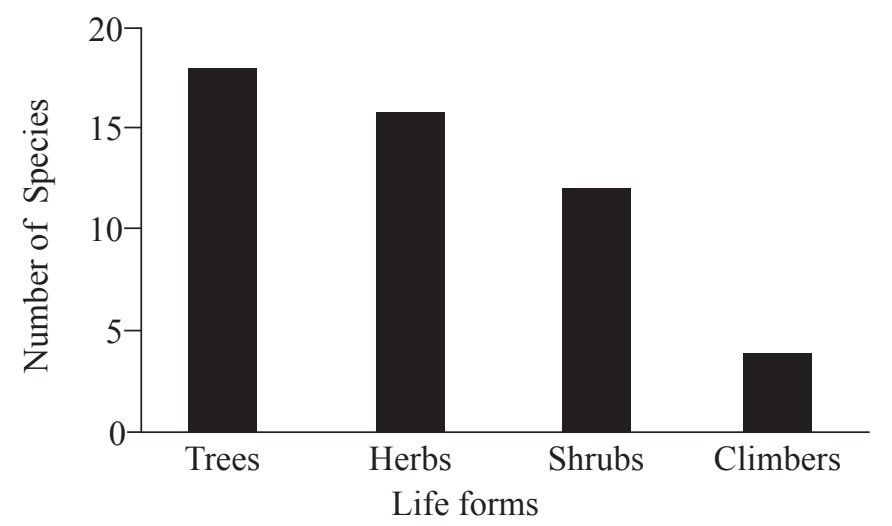

Figure 3: Frequency of wild edible plant taxa arranged by life forms

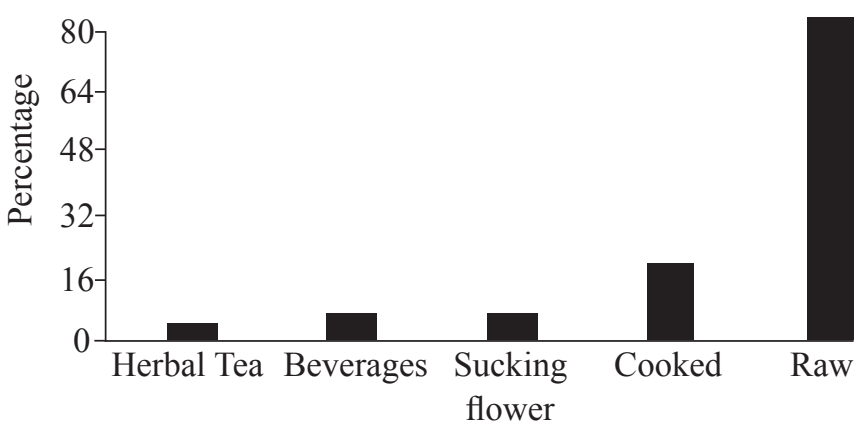

Figure 4: Mode of consumption of wild edible plants in percent

indicates the less dependency of the children on their parents. This trend has its own positive effect on the education activity of the children since the market in Hula district is twice a week, which could not harm the school time of the children. Its effect seems positive since the children do manage and cover their education and accommodation fees. This trend indicates if the number and amount of marketable wild edible plant increases, it might help the communities to get extra income for their families. As a result, the poverty level of the community could partly be alleviated. These scenarios indicated the importance of wild edible plants for food security and poverty reduction if managed in a proper manner.

\subsection{Medicinal value of wild edible plants}

The study revealed that among the recorded wild edible plants, 31 species $(62 \%)$ have been cited as medicinal plants. Most of the medicinal plants were trees (11 species) and herbs ( 9 species) followed by shrubs (8 species), and the least were climbers ( 3 species). Moraceae and Rosaceae were the most frequently used plant families (Table 3). Leaves and stem barks were predominately used to prepare remedies for ailments. For example, the barks of Carrisa spinarum and Pavetta abyssinica are mixed together, powdered, cooked and then taken orally as remedy for erectile dysfunction and Gonorrhea (Siimmaxo).

Dominance of medicinal plant species from families Moraceae and Rosaceae could be attributed to their wider distribution and abundance in the flora area. This is also confirmed by consistent recording of ethno medicinal uses of species from the aforementioned families in different Ethiopian ethnobotanical studies (Chekole, Asfaw, and Kelbessa, 2015; Kefalew, Asfaw, and Kelbessa, 2015; Lulekal et al., 2013; Teklehaymanot and Giday, 2010). Moreover, the wide utilization of species from these families might relate to the presence of effective antioxidants and other pharmaceutical ingredients against

\begin{tabular}{|c|c|c|c|c|c|}
\hline Scientific name & Family & Local name & Habits & $\begin{array}{l}\text { Marketable parts } \\
\text { /products }\end{array}$ & $\begin{array}{l}\text { Age groups } \\
\text { marketed }\end{array}$ \\
\hline Morus alba $\mathrm{L}$. & Moraceae & Boowili go'ra & Shrub & Fruit & Children, young \\
\hline Oleaeuropaea sub sp. cuspidata. & Oleaceae & Ejersa & Tree & Leaves and stem & All age groups \\
\hline Prunus africana (Hook.f.) Kalklm & Rosaceae & Garbicho & Tree & Timber, furniture & Young/adult, old \\
\hline Rhamnus prinoides L'Herit.R.Staddo.A.Rich. & Rhamnaceae & Xaddo & Tree & Leaves and stem & All age groups \\
\hline Rubus volkensii Engl. & Rosaceae & Allichchu Go'ra & Shrub & Fruit & Children, young \\
\hline Solanum nigrum L. & Solanaceae & Xu'naayye & Herb & Leaves and stem & All age groups \\
\hline Syzygium guineense (Willd.) Dc. & Myrtaceae & Duuwancho & Tree & Fruit, timber, furniture & All age groups \\
\hline Thymus serrulatus Hochst. & Lamiaceae & Xooshine & Herb & Whole parts & All age groups \\
\hline Urtica simensis Steudul. & Urticaceae & Laaleessa & Herb & Leaves and Stem & All age groups \\
\hline Vepris dainelli (Pichi-Sperm) Kokwaro & Rutaceae & Lelcho & Tree & Fruit & Children, young \\
\hline
\end{tabular}




\begin{tabular}{l}
\hline Table 3: Lists of medicinal wi \\
\hline Scientific name \\
\hline Acokanthera schimperi \\
(A.DC.) Schweinf. \\
Carissa spinarum L. \\
\\
Cordia \\
africana Lam. \\
Datura stramonium L. \\
Dovyalis abyssinica \\
(A. Rich) Warb. \\
Ehretia cymosa Thonn. \\
Ekebergia capensis Sparrm. \\
Embelia schimperi Vatke.
\end{tabular}

Ferula communis L. Ficus sur Forssk.

Ficus vasta Forssk.

Lagenaria siceraria (Molina) Standl. Justicia schimperiana (Hochst.exA.Nees) T. Anders Kniphofiai-soetifolia Steud. ex Hochst

Maesa lanceolata

Forssk.

Monordica foetida

Schumach.

Acokanthera schimperi

(A. DC.) Schweinf.

Carissa spinarum L.

Cordia africana Lam.

Datura stramonium L. Dovyalis abyssinica (A. Rich) Warb. Ehretia cymosa Thonn. Ekebergia capensis Sparrm. Embelia schimperi Vatke.

Ways of preparation and application

Fresh leaves/stem barks crushed and pounded with water, filtered and drunk until recovery to treat gonorrhea and amoeba. Dry seeds tied on the neck for children as remedy for evil eye.

Root of Carissa spinarumis pounded and dried. Dry smoke is used as treatment for evil eye and headache through nose. Its bark and bark of Pavetta abyssinica mixed together and then powdered, cooked and took orally as remedy for male impotence (when penis do not erect during sexual intercourse) and gonorrhea (Siimmaxo).

Fresh stem bark chewed to treat teeth problem and sudden sickness. Its leaf is burned and the remaining ash is mixed with butter and creamed on affected part through dermal.

Fresh leaves pounded and parted on the head as the remedy for head ache.

Its bark is used as remedy for tooth disease.

Fresh stem bark crushed, pounded and mixed with water and drunk as remedy for Stomach problem. Bark of Ekebergia capensisis powdered and half a spoon is added to wound.

Its seed is dried and powdered, mixed with water, two glasses is taken once as remedy for anthelmintic. Its leaf and seed and leaf of Croton macrostchys (Masincho; non-edible) are pounded together and one glass is taken by human to treat intestinal parasites (Soichotedhibba).

Its young shoot drunk with coffee or tea; leaves are inhaled to treat common cold.

Dry fruits pounded, powdered and then parted on wound. Fresh stem barks crushed, pounded, boiled, and cooled, then drunk twice as tea to treat acute bleeding and vomiting.

Sap from Ficusvastaand powdered root of Pterolobium stellatum (Kontir/ Kentaffa, Amharic) are mixed together and creamed to the external hemorrhoid given through anal.

Ripe fruit is bored, rinsed with cold water, 2-3 cup of coffee is drunk early in the morning before breakfast to treat jaundice (Magartotedhibba). Fresh fruit is creamed to the affected body to treat scabies.

Fresh Leaf heated on fire, and then salt is added and tied on the swollen part to treat leg swelling.

Its root is cooked and then given orally to horses to treat yekolabeshita (Gammoojjetedhibba, Sidama Language) and children as the remedy for intestinal parasites (Ameessa).

Dry leaves are pounded with water and powdered then given orally to treat skin infection, lung T.B. (Butaamudhibba).

Fresh roots chewed and swallowed after breakfast as a remedy for gonorrhea. Also, fresh leaves crushed, pounded and filtered, then mixed with goat milk and drunk in the morning to treat intestinal parasites for both live stock (Birretedhibba) and human beings.

Fresh leaves/stem barks crushed and pounded with water, filtered and drunk until recovery to treat gonorrhea and amoeba. Dry seeds tied on the neck for children as remedy for evil eye.

Root of Carissa spinarumis pounded and dried. Dry smoke is used as treatment for evil eye and headache through nose.Its bark and bark of Pavetta abyssinicamixed together and then powdered, cooked and took orally as remedy for male impotence (when penis do not erect during sexual intercourse) and gonorrhea (Siimmaxo).

Fresh stem bark chewed to treat teeth problem and sudden sickness. Its leaf is burned and the remaining ash is mixed with butter and creamed on affected part through dermal.

Fresh leaves pounded and parted on the head as the remedy for head ache.

Its bark is used as remedy for tooth disease.

Fresh stem bark crushed, pounded and mixed with water and drunk as remedy for Stomach problem. Bark of Ekebergia capensisis powdered and half a spoon is added to wound.

Its seed is dried and powdered, mixed with water, two glasses is taken once as remedy for anthelmintic. Its leaf and seed and leaf of Croton macrostchys (Masincho; non-edible)are pounded together and one glass is taken by human to treat intestinal parasites (Soichotedhibba).

continue.... 


\begin{tabular}{l} 
Table 3: Lists of medicinal wild \\
\hline Scientific name \\
\hline Ferula communis L. \\
Ficus sur Forssk. \\
Ficus vasta Forssk. \\
Lagenaria \\
siceraria (Molina) Standl. \\
Justicia schimperiana \\
(Hochst.exA.Nees) T. Anders \\
Kniphofiai-soetifolia Steud. \\
ex Hochst \\
Maesa lanceolata \\
Forssk. \\
Monordica foetida \\
Schumach.
\end{tabular}

Morus alba $\mathrm{L}$.

Oleaeuropaea sub sp. cuspidata (Wall. ex G. Don) Cif.

Prunus africana

(Hook.f.) Kalklm

Rhamnus prinoides

L Herit.R. Staddo. A. Rich.

Rosa abyssinica Lindley.

Rubus volkensii Engl.

Rumex abyssinicus Jaccq.

Sauromatum venosum (Ait.)

Kunth

Sida ovata Forssk.

Solanum nigrum $\mathrm{L}$.

Syzygium guineense

(Willd.) Dc.

Thymus serrulatus Hochst.

Urtica simensis

Steudul.

Vernonia

amygdalina

Del.

Yushaniaalpina

K. Schum
Ways of preparation and application

Its young shoot drunk with coffee or tea; leaves are inhaled to treat common cold.

Dry fruits pounded, powdered and then parted on wound. Fresh stem barks crushed, pounded, boiled, and cooled, then drunk twice as tea to treat acute bleeding and vomiting.

Sap from Ficus vasta and powdered root of Pterolobium stellatum (Kontir/Kentaffa, Amharic) are mixed together and creamed to the external hemorrhoid given through anal.

Ripe fruit is bored, rinsed with cold water, 2-3 cup of coffee is drunk early in the morning before breakfast to treat jaundice (Magartotedhibba). Fresh fruit is creamed to the affected body to treat scabies.

Fresh leaf heated on fire, and then salt is added and tied on the swollen part to treat leg swelling.

Its root is cooked and then given orally to horses to treat yekolabeshita (Gammoojjetedhibba, Sidama Language) and children as the remedy for intestinal parasites (Ameessa).

Dry leaves are pounded with water and powdered then given orally to treat skin infection, lung T.B (Butaamudhibba).

Fresh roots chewed and swallowed after breakfast as a remedy for gonorrhea.Also, fresh leaves crushed, pounded and filtered, then mixed with goat milk and drunk in the morning to treat intestinal parasites for both live stock (Birretedhibba) and human beings.

Its leaf is cooked and then children take orally to treat intestinal parasites (Ameessa).

Dry/fresh branches used as tooth brush and chewed to treat teeth problem.

Fresh leaves boiled and the infusion drunk in the morning as remedy for intestinal parasites. Fresh leaves also chewed and then sprayed on the eye as remedy for eye disease (Burdicha) and on the cattle to treat Evil eye (Budakko).

Dry stem bark is crushed, pounded and powdered then put on wound both human and livestock.

Fresh leaves rubbed on the infected skin.Also fresh leaves powdered and then given live stock to treat lung T.B (Butaamudhibba).

Fresh leaves are powdered and then drunk orally to treat hypertension and diabetes.

Fresh leaves are chewed and sprayed on the swollen part to treat body swelling and stomach problem.

Fresh roots pounded and boiled and then mixed with milk and drunk in the morning for two days as remedy for amoeba and intestinal parasites. Dry roots chewed and swallowed to treat Goiter.

The roots/tubers are cooked and then taken orally as remedy for intestinal parasites both human and livestock.

Fresh leaf pounded and mixed with the leaf of Vernonia auriculifera (Reejje; non-edible) and parted on skin infection, wound.

Fresh leaves cooked and eaten as vegetables to treat intestinal parasites, gonorrhea, jaundice (Magartotedhibba).

Decoctation of barks powder is employed as remedy for diarrhea.Its bark is cooked and then drunk a cup of coffee for human being and 3 cups of coffee locally known as Kunuune for livestock to treat lung T.B. (Buutaamudhibba).

Its fresh leaves are mixed with tea and then drunk as the remedy for hypertension.

Whole plants parts crushed and pounded then decoction part are drunk in the morning 2-3 days to treat gonorrhea (human). Dry/fresh leaves are crushed, pounded and filter then drunk and painting on the body to treat evil eye (both).

Bathing with crushed fresh leaves to treat devil disease; to clean evil eye and evil work from home, crushed leaves are sprayed on utensils, on bed and gate (Sheexaanu Dhibba). For tooth infection, leaves are chewed with bulb of Allium sativum (Waajjotuma).

Dry leaves crushed and pounded with water and then drunk in the morning as remedy for intestinal parasites. Also its fresh leaves are chewed and then sprayed on the infected skin. Locally known as Biifa. 
ailments (Onyekwelu et al., 2015). The high representation of medicinal wild edible plant from trees can be explained the culture and tradition of the people in the study area, where medicine is considered as secret to other local people. This is to increase the medicinal effect of the collected plants, as the locals believes that talking about the medicine reduces the medicinal value and curative effect of the plants. This could be related to the fact that trees are not easily accessible to the nearby villages. This finding is significantly different from all the other findings from other regions of Ethiopia, where herbs dominating the medicinal plants (Chekole et al., 2015; Feyssa et al., 2015; Giday et al., 2009; Kefalew et al., 2015; Lulekal et al., 2013). This further could be explained since the study is focused on wild edible plants than medicinal plants. If the study is focused on medicinal plants, the trend of dominance might change. In general, the medicinal value of the wild edible plants has its own multipurpose activity of the collected plant species in Hula district. This further helps to increase their importance for food security, health and poverty alleviation.

\subsection{Time and frequency for harvesting of wild edible plants}

The time and frequency of harvesting varies from plant to plant depending on its availability, and from place to place due to ecological and climatic conditions (Figure 6). Over $64 \%$ of the wild edible plants were consumed during times of food scarcity and starvation from February to May where the stored cultivated food crops are dwindling progressively (Table 4). These plants were used as substitutes and fill the gap of food deficiency that happens between harvesting seasons. For example, Sauromatum venosum, Solanum nigrum and Urtica simensis were collected during times of food scarcity and starvation in the study area. In addition, Maesa lanceolata, Syzygium guineense and Vepris dainelli produce edible parts between March and April. Moreover, some other wild edible plants such as Cajanus cajan, Datura stramonium, Morus alba, Physalis peruviana, Rubus apetalus and R. volkensii were collected during Birra (autumn). On the other hand, some species, such as Apodytes dimidiata, Canthium oligocarpum sub sp. oligocarpum, Cyperus usitatus, Ferula communis, Oleaeuropaea sub sp. cuspidata, Rhamnus prinoides, Rumex abyssinicus, Sauromatum venosum, Solanum nigrum, Thymus serrulatus, Urtica simensis and Vernonia amygdalina were available throughout the year.

The study area, Hula district, exhibits the characteristics of the sub-Saharan climate. Thinking in global perspective, we can explain one of the most important issue of the district is hunger. Food production is great a concern as the world's population rises. Currently, $20 \%$ of the population of the subSaharan regions are affected by malnutrition, and people in this region are undernourished, and lacking the average calorie intake. Sustainable consumption of wild edible plants in the Hula district indicates the mechanism to reduce the effect of malnutrition and hanger by using wild edible plants. However, there is a need to blend indigenous knowledge with modern science to promote sustainable development, and sustained utilization of these uncultivated sources of nutritious food (Fentahun and Hager, 2009; Grafton et al., 2015; Mahapatra and Panda, 2012). In that context, it is seen that international studies on the subject is on the increase as a consequence of the understanding of wild edible plants' importance in alleviating malnutrition and sustain ethnic value of the society.

\subsection{Knowledge and use of wild edible plants based on age,} education level and gender

Many of the local people had knowledge of wild edible plants, including their time of fruiting and ripening (Figure 7 and Table 5). Figure 7 (A) indicated that there is no significant difference between the level of education of the informants and the number of wild edible plants they know. However, Figure 7 (B) clearly shows significant $(p<0.001)$ difference in the age and gender of the informants towards the number of wild edible plants they know. This means as the age of informant increases, the indigenous knowledge of people on wild edible plants clearly increases. Elders knows more wild edible plants than youngsters. There is no significant difference on the knowledge of wild edible plants based on level of education $(p<0.17)$ of the informants. However there is significant difference on the number of knowledge of wild edible plants between men and women informants showed a significant difference $(p<0.001)$. Men informants of the district reported more wild edible plants on average better than women (3.27 \pm 0.14$)$. This could be related to the gender role stereotyping in Hula district as it is more expressed in Sidama Zone and other parts (Molla et al., 2011; Sansanelli and Tassoni, 2014; Zegeye et al., 2014). Culturally, Sidama women are not allowed to move from one place to another. Rather they stay more in their own or neighbors garden. This might have resulted in the reduced knowledge of wild edible plants of women compared to men. The result further showed that as the age of the informants both men and women, increased their level of knowledge about wild edible plants also increased. This might be due to the number of new plants they experience as their age increased. However, young informants tend to know less number of wild edible plants. This also explains that generally, gender and age based differences in knowledge of wild edible plants can be derived from experience and degree of cultural contact with food plants. As a result, in this modern era where the malnutrition and fast and mono cultured foods 


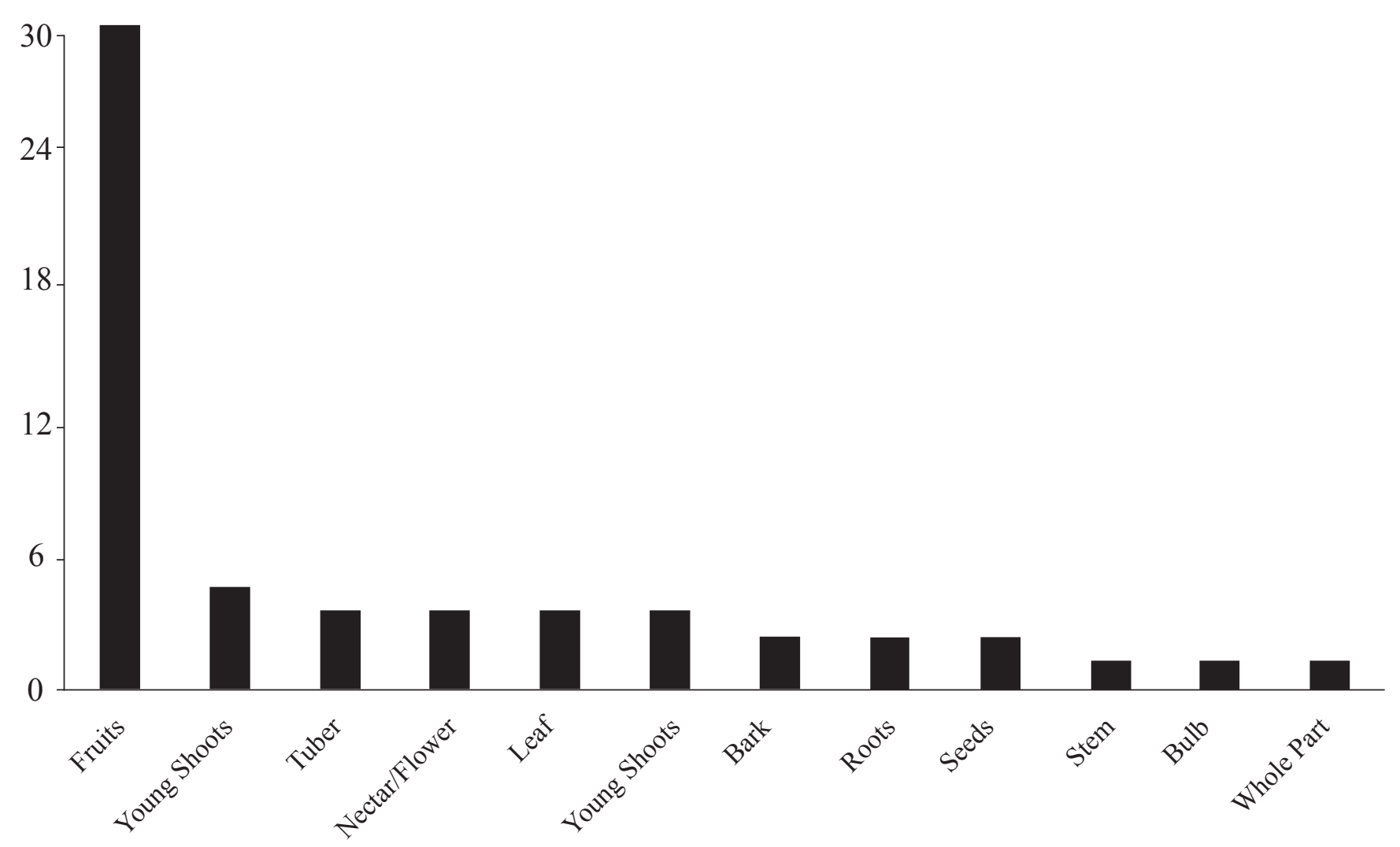

Figure 5: Use frequency of wild edible plant parts

\begin{tabular}{ll}
\hline \multicolumn{2}{l}{ Table 4: List of wild edible plants used in rainy season } \\
\hline Botanical name & Parts used \\
\hline Arisaema flavum (Forssk.) Schott. & Tuber \\
Chenopodium album L. & Young leaf and \\
& stem \\
Eriose macordifolium Hochst. ex A.Rich & Root \\
Eriose maverdickii Dewild. & Root \\
Morus alba L. & Fruit \\
Physalis peruviana L. & Fruit \\
Rubus volkensii Engl. & Fruit \\
Sauromatum venosum (Ait.) Kunth & Tuber \\
Solanum nigrum L. & Leaf and stem \\
Urtica simensis Steudul. & Leaf and stem \\
\hline
\end{tabular}

is increasing, and the transfer of ethnobotanical knowledge from old generation to the young is decreasing, this study will be beneficial in terms of both recording of information regarding the consumption of wild edible plants as food source and providing new ideas on nourishment providing plants. It is a matter of urgency to record the traditional knowledge of wild edible plant throughout the Sidama Zone of the SNNPR government of Ethiopia, to increase food security thereby alleviating malnutrition.

Furthermore, the number of wild edible plants known by

\begin{tabular}{|c|c|c|c|c|c|c|}
\hline Source & Df & $\begin{array}{c}\text { Sum } \\
\text { square }\end{array}$ & $\begin{array}{l}\text { Mean } \\
\text { square }\end{array}$ & $\begin{array}{c}\mathrm{F} \\
\text { value }\end{array}$ & $\begin{array}{c}\operatorname{Pr} \\
(>\mathrm{F})\end{array}$ & $\begin{array}{l}\text { Signif- } \\
\text { icance }\end{array}$ \\
\hline Sex & 1 & 102.0 & 102.0 & 50.98 & $\begin{array}{c}1.10 \mathrm{E}- \\
10\end{array}$ & *** \\
\hline Age & 1 & 391.4 & 391.4 & 195.54 & $\begin{array}{c}2.20 \mathrm{E}- \\
16\end{array}$ & *** \\
\hline Education level & 1 & 3.8 & 3.8 & 1.89 & 0.17 & \\
\hline Sub-districts & 7 & 32.7 & 4.7 & 2.33 & 0.02 & $*$ \\
\hline Residuals & 109 & 218.2 & 2 & & & \\
\hline
\end{tabular}

each informants was significantly different $(p=0.02)$ between the selected sub districts. As it is described in the material and method section, the climate condition are either dega or woinadega. This happen because the selected sub-districts differ in their climate conditions which intern brought difference on the knowledge level of the informants.

This result proved the role played by wild edible plants and the local community holding considerable traditional knowledge about the importance of these plants in assisting the food security and adverse climate change preparedness of the community. This traditional knowledge about wild edible plants played major roles for the people of Hula district to 


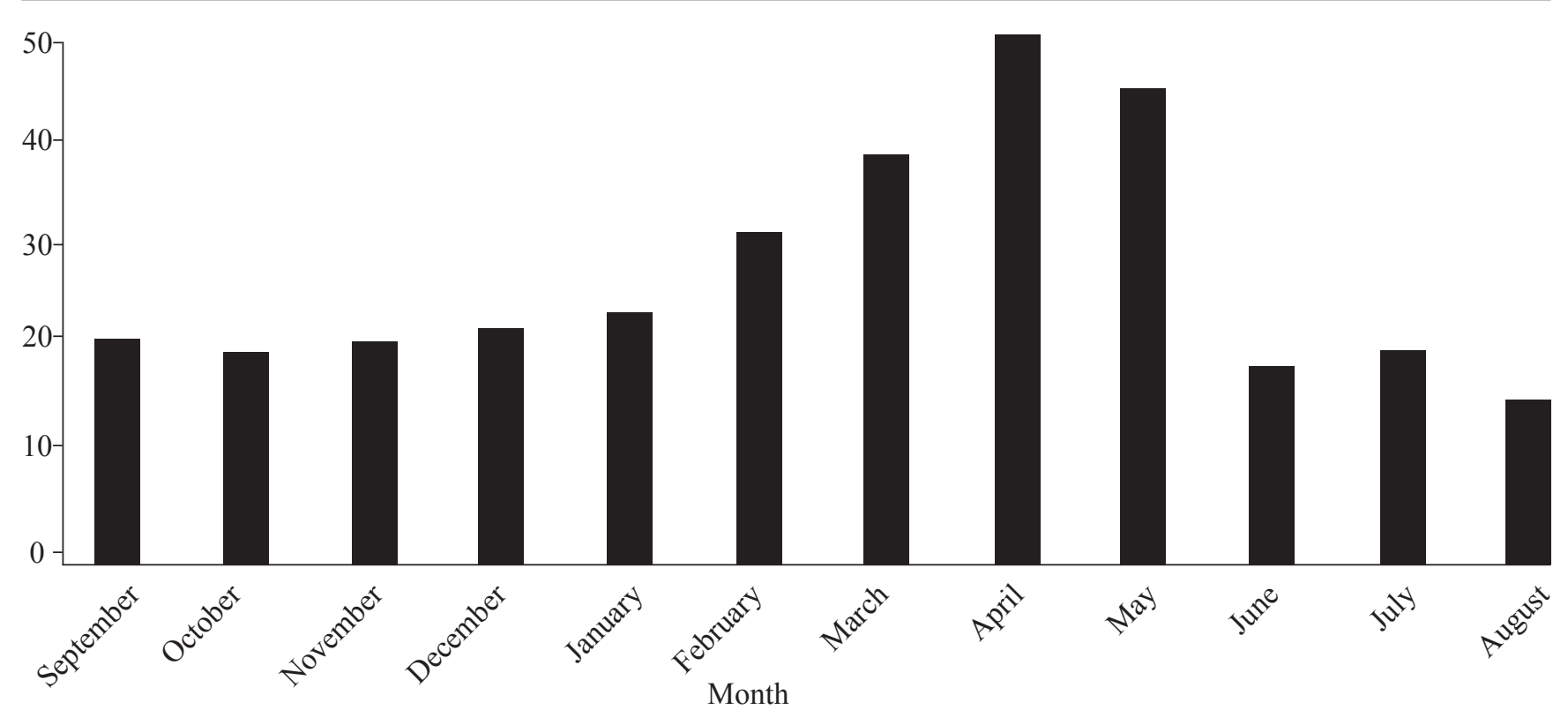

Figure 6: Number of wild edible plants consumed and time of gathering within a year, Hula district, Sidama Zone, SNNPR
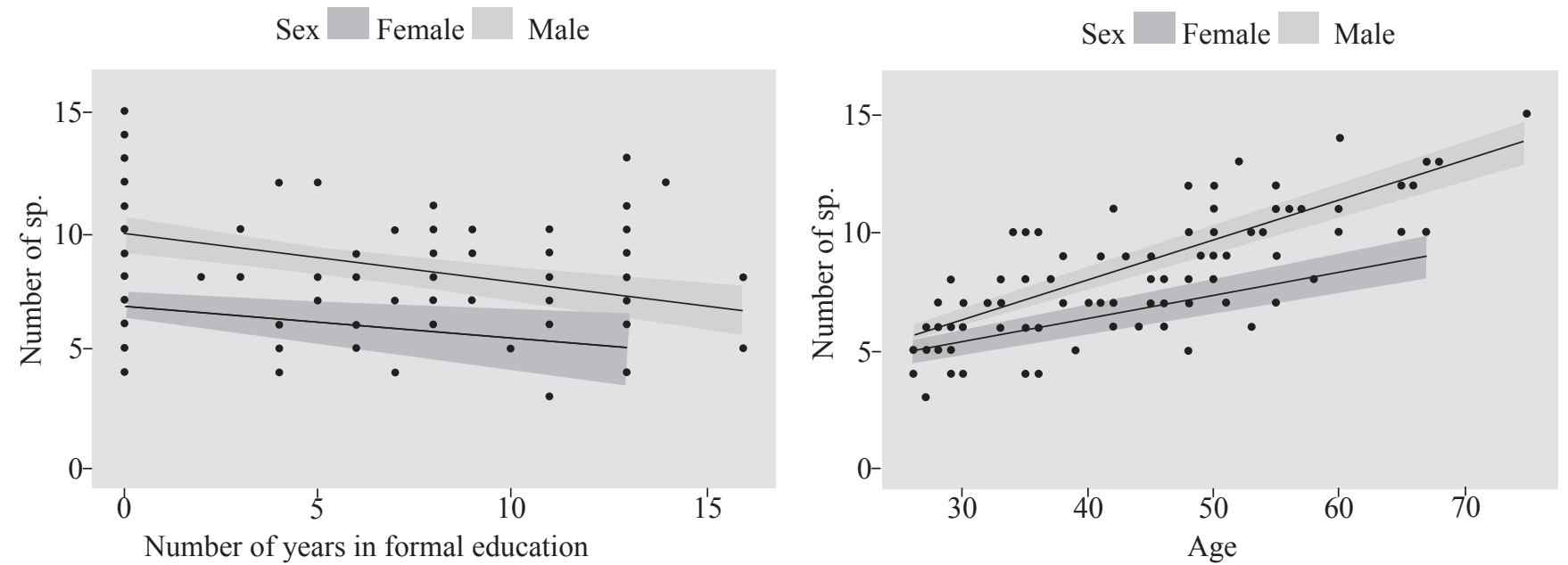

Figure 7: Regression of (A) the number of Education spent at formal school on the number of wild edible plants species known by the informants (B) age of the individual on the number of wild edible plants species known by the informants. Shaded lines mark the $95 \%$ confidence interval

partly rely on wild edible plants. This cultural factor might have been contributed in the adherence of the community to the ancestral practices by upholding the value of their mothers and fathers.

\section{Conclusion}

Knowledge of wild edible plants depends on the socio cultural factors rather than biological. Information exchange, close contact to nature in everyday life, taste preference and cultural values are the main factors for consuming wild edible plants. The habit of eating vegetables and wild fruits are major reasons to accept or reject the wild edible plants.

\section{Further Research}

Further research is undergoing to characterize the nutritional quality of wild edible plants in Hula district.

\section{Acknowledgement}

We are grateful to everyone who kindly shared their knowledge and time. We hope to have contributed to saving and spreading their valuable knowledge. We also thank the Ethiopian Ministry of Education for the grants made to Benta Sina.

\section{References}

Addis, G., Asfaw, Z., Woldu, Z., 2013a. Ethnobotany of 
Wild and Semi-wild Edible Plants of Konso Ethnic Community, South Ethiopia. Ethnobotany Research and Application 11, 121-141.

Addis, G., Asfaw, Z., Woldu, Z., 2013b. The Role of Wild and Semi-wild Edible Plants to Household Food Sovereignty in Hamar and Konso Communities, South Ethiopia. Ethnobotany Research and Application 11, 251-271.

Addis, G., Urga, K., Dikasso, D., 2005. Ethnobotanical study of edible wild plants in some selected districts of Ethiopia. Human Ecology 33, 83-118.

Afolayan, A.J., Jimoh, F.O., 2009. Nutritional quality of some wild leafy vegetables in South Africa. International Journal of Food Science and Nutrition 60, 424-431.

Assefa, A., Abebe, T., 2014. Ethnobotanical Study of Wild Medicinal Trees and Shrubs in Benna Tsemay district, Southern Ethiopia. Journal of Science and Development 2,1 .

Basu, S., Das, M., Sen, A., Roy Choudhury, U., Datta, G., 2014. Analysis of complete nutritional profile of Amorphophallus campanulatus tuber cultivated in Howrah district of West Bengal, India. Asian Journal of Pharmaceutical and Clinical Research 7, 3.

Bhattarai, S., Chaudhary, R.P., Taylor, R.S.L., 2009. Wild edible plants used by the people of Manang district, Central Nepal. Ecology of Food and Nutrition 48, 1-20.

Bizuayehu, T., 2008. On Sidama folk identification, naming, and classification of cultivated enset (Ensete ventricosum) varieties. Genetic Resource and Crop Evolution 55, 13591370.

Boedecker, J., Termote, C., Assogbadjo, A.E., Van Damme, P., Lachat, C., 2014. Dietary contribution of Wild Edible Plants to women's diets in the buffer zone around the Lama forest, Benin-an underutilized potential. Food Security 6, 833-849.

Campos, L.Z. de O., Albuquerque, U.P., Peroni, N., Araújo, E.L., 2015. Do socioeconomic characteristics explain the knowledge and use of native food plants in semiarid environments in Northeastern Brazil? Journal of Arid Environment 115, 53-61.

Chekole, G., Asfaw, Z., Kelbessa, E., 2015. Ethnobotanical study of medicinal plants in the environs of Tara-gedam and Amba remnant forests of Libo Kemkem district, northwest Ethiopia. Journal of Ethnobiology and Ethnomedicine 11, 4.

Danver, S.L., 2015. Native Peoples of the World: An Encylopedia of Groups, Cultures and Contemporary Issues. Routledge, 1030.

Demessie, A., Singh, B.R., Lal, R., 2015. Land Degradation and Soil Carbon Pool in Different Land Uses and Their Implication for Food Security in Southern Ethiopia, in: Lal, R., Singh, B.R., Mwaseba, D.L., Kraybill, D., Hansen, D.O., Eik, L.O. (Eds.), Sustainable Intensification to Advance Food Security and Enhance Climate Resilience in Africa. Springer International Publishing, 45-62.

Duncan, J., 2015. Global Food Security Governance: Civil Society Engagement in the Reformed Committee on World Food Security. Routledge, 192.

Fentahun, M., Hager, H., 2009. Integration of indigenous wild woody perennial edible fruit bearing species in the agricultural landscapes of Amhara region, Ethiopia. Agroforestry System 78, 79-95.

Fentahun, M.T., Hager, H., 2009. Exploiting locally available resources for food and nutritional security enhancement: wild fruits diversity, potential and state of exploitation in the Amhara region of Ethiopia. Food Security 1, 207-219.

Feyssa, D.H., Abdeta, C., Berhan, T., Sharma, M., 2015. Medicinal plants use and conservation practices in Jimma Zone, South West Ethiopia. International Journal of Biodiversity and Conservation 7, 202-210.

Friel, S., Ford, L., 2015. Systems, food security and human health. Food Security 7, 437-451.

Getachew, G.A., Asfaw, Z., Singh, V., Woldu, Z., BaiduForson, J.J., Bhattacharya, S., 2013. Dietary values of wild and semi-wild edible plants in Southern Ethiopia. African Journal of Food Agriculture and Nutrition 13.

Giday, M., Asfaw, Z., Woldu, Z., 2009. Medicinal plants of the Meinit ethnic group of Ethiopia: An ethnobotanical study. Journal of Ethnopharmacology 124, 513-521.

Grafton, R.Q., Daugbjerg, C., Qureshi, M.E., 2015. Towards food security by 2050. Food Security 7, 179-183.

Jman Redzic, S., 2006. Wild edible plants and their traditional use in the human nutrition in Bosnia-Herzegovina. Ecology of Food and Nutrition. 45, 189-232.

Joshi, N., Mitchard, E.T., Woo, N., Torres, J., Moll-Rocek, J., Ehammer, A., Collins, M., Jepsen, M.R., Fensholt, R., 2015. Mapping dynamics of deforestation and forest degradation in tropical forests using radar satellite data. Environmental Research Letter 10, 034014.

Ju, Y., Zhuo, J., Liu, B., Long, C., others, 2013. Eating from the wild: diversity of wild edible plants used by Tibetans in Shangri-la region, Yunnan, China. Journal of Ethnobiology and Ethnomedicine 9, 28.

Kang, Y., Luczaj, L., Kang, J., Wang, F., Hou, J., Guo, Q., 2014. Wild food plants used by the Tibetans of Gongba Valley (Zhouqu County, Gansu, China). Journal of Ethnobiology and Ethnomedicine 10, 20. 
Kayang, H., 2007. Tribal knowledge on wild edible plants of Meghalaya, Northeast India. Indian Journal of Traditional Knowledge 6, 177-181.

Kefalew, A., Asfaw, Z., Kelbessa, E., 2015. Ethnobotany of medicinal plants in Ada'a district, East Shewa Zone of Oromia Regional State, Ethiopia. Journal of Ethnobiology and Ethnomedicine 11, 25.

Kidane, B., van der Maesen, L.J.G., Asfaw, Z., Sosef, M.S.M., van Andel, T., 2014a. Wild and semi-wild leafy vegetables used by the Maale and Ari ethnic communities in southern Ethiopia. Genetic Resource and Crop Evolution 1-14.

Kidane, B., van der Maesen, L.J.G., van Andel, T., Asfaw, Z., Sosef, M.S.M., 2014b. Ethnobotany of Wild and SemiWild Edible Fruit Species used by Maale and Ari Ethnic Communities in Southern Ethiopia. Ethnobotany Research and Application 12, 455-471.

Lamien-Meda, A., Lamien, C.E., Compaoré, M.M., Meda, R.N., Kiendrebeogo, M., Zeba, B., Millogo, J.F., Nacoulma, O.G., 2008. Polyphenol content and antioxidant activity of fourteen wild edible fruits from Burkina Faso. Molecules 13, 581-594.

Lulekal, E., Asfaw, Z., Kelbessa, E., Van Damme, P., 2013. Ethnomedicinal study of plants used for human ailments in Ankober district, North Shewa Zone, Amhara region, Ethiopia. Journal of Ethnobiology and Ethnomedicine 9, 63.

Mahapatra, A.K., Panda, P.C., 2012. Wild edible fruit diversity and its significance in the livelihood of indigenous tribals: Evidence from eastern India. Food Security 4, 219-234.

Molla, E.L., Asfaw, Z., Kelbessa, E., Van Damme, P., 2011. Wild edible plants in Ethiopia: a review on their potential to combat food insecurity. Africa Focus 24, 71-121.

Nedelcheva, A., 2013. An ethnobotanical study of wild edible plants in Bulgaria. EurAsian Journal of Bioscience 7, 77-94.

Nedelcheva, A., Dogan, Y., 2011. Usage of plants for weather and climate forecasting in Bulgarian folk traditions. Indian Journal of Traditional Knowledge 10, 91-95.

Nedelcheva, A., Dogan, Y., Petkovic, D.O., Padure, L.M., 2011. The use of wild edible plants in western and central Anatolia (Turkey). Economic Botany 58, 684-690.

Ojelel, S., Kakudidi, E.K., 2015. Wild edible plant species utilized by a subsistence farming community in Obalanga subcounty, Amuria district, Uganda Journal of Ethnobiology and Ethnomedicine 11, 7.

Onyekwelu, J.C., Oyewale, O., Stimm, B., Mosandl, R., 2015. Antioxidant, nutritional and anti-nutritional composition of Garcinia kola and Chrysophyllum albidum from rainforest ecosystem of Ondo State, Nigeria. Journal of Forest Resource 26, 417-424.
Pardo-de-Santayana, M., Tardío, J., Blanco, E., Carvalho, A.M., Lastra, J.J., San Miguel, E., Morales, R., 2007. Traditional knowledge of wild edible plants used in the northwest of the Iberian Peninsula (Spain and Portugal): a comparative study. Journal of Ethnobiology and Ethnomedicine 3, 27.

Qi, X., Vitousek, P.M., Liu, L., 2015. Provincial food security in China: a quantitative risk assessment based on local food supply and demand trends. Food Security 1-12.

Redzic, S.J., 2006. Wild Edible Plants and Their Traditional Use in the Human Nutrition in Bosnia-Herzegovina. Ecology of Food and Nutrition 45, 189-232.

Regassa, T., Kelbessa, E., Asfaw, Z., 2015a. Ethnobotany of Wild and Semi-Wild Edible Plants of Chelia district, WestCentral Ethiopia. Science, Technology and Arts Research Journal 3, 122-134.

Regassa, T., Kelbessa, E., Asfaw, Z., 2015b. Ethnobotany of Wild and Semi-Wild Edible Plants of Chelia district, WestCentral Ethiopia. Science, Technology and Arts Research Journal 3, 122-134.

Rivers, J., Warthmann, N., Pogson, B.J., Borevitz, J.O., 2015. Genomic breeding for food, environment and livelihoods. Food Security 7, 375-382.

Salawu, A., Aseres, A., 2015. Language policy, ideologies, power and the Ethiopian media. Communication 41, 71-89.

Salih, N.K.-E.M., Ali, A.H., 2014. Wild food trees in Eastern Nuba Mountains, Sudan: Use diversity and threatening factors. Journal of Agriculture and Rural Development in the Tropics and Subtropics 115, 1-7.

Sansanelli, S., Tassoni, A., 2014. Wild food plants traditionally consumed in the area of Bologna (Emilia Romagna region, Italy). Journal of Ethnobiology and Ethnomedicine 10, 69.

Sneyd, L.Q., 2015. Zoning in: The contributions of buyamsellams to constructing Cameroon's wild food zone. Geoforum 59, 73-86.

Tebkew, M., Asfaw, Z., Zewudie, S., others, 2014. Underutilized wild edible plants in the Chilga district, northwestern Ethiopia: focus on wild woody plants. Agriculture and Food Security 3, 12.

Teklehaymanot, T., Giday, M., 2010. Ethnobotanical study of wild edible plants of Kara and Kwego semi-pastoralist people in Lower Omo River Valley, Debub Omo Zone, SNNPR, Journal of Ethnobiology and Ethnomedicine $6,23$.

Zegeye, H., Teketay, D., Kelbessa, E., 2014. Socio-Economic Factors Affecting Conservation and Sustainable Utilization of the Vegetation Resources on the Islands of Lake Ziway, South-Central Ethiopia. Natural Resource 5, 864-875. 